\title{
LAND MANAGER PROFESSION ON LABOR MARKET: CONDITION AND PROBLEMS OF REQUEST AND DEMAND
}

\author{
Tretiak A.M., Doctor of Economics, Professor, Corresponding Member of the National \\ Academy of Sciences of Ukraine \\ Tretiak V.M., Doctor of Economics, Professor, State Ecology Academy of Postgraduate \\ Education and Management
}

Dorosh I.M., Doctor of Economics, Associate Professor

Dorosh O.S., Doctor of Economics, Professor

National University of Life and Environmental Sciences of Ukraine

\section{E-mail:nnieco@ukr.net}

The article analyses the state of the most popular and least popular professions and specialties in Ukraine. It's found that there are no specialties in the field of land management among them. It is also noted that at the legislative level the specialties "Land Management and Cadastre" and "Evaluation of land and real estate" were replaced by the specialty "Geodesy and land management", which belongs to the field of knowledge "Architecture and construction" (technical sciences). It is substantiated that the profession of land manager should relate to the field of knowledge of "Social and behavioural sciences". It's based on the provisions of the Law "On Land Management" and the study of world experience of the essence of the concepts of land management and land management planning (both have technical, socio-economic, legal and environmental focus).

It is proved that the profession of land manager needs to be reprofiled. In this regard, there is a need to identify new specialties and specializations and add them into the state classifier DK 003: 2010. It's important to expand the training of specialists within: 1) specialty 193 "Geodesy and land management" specializations "Land Management and Land Use Administration" and "Cadastral Registrar"; 2) specialty 101 "Ecology" specialization "Land management and ecologization of land

use", 3) specialty 051 "Economics" specialization "Economics of land management and land use". It is proposed to add them to the classifier.

Keywords. Profession "land manager", labour market, perspective specialties and specializations in land management, new qualifications.

Formulation of the problem. The development of society at all times was associated with the arrangement of lands, which today remains the main means for the existence of mankind and a source of social wealth. The need to establish the limits disturb landowners from ancient times. This function is performed by land surveyors. When the first representatives of this profession appeared, it is certainly not known. But the land surveyor is now a profession demanded both in the village and in the city. In our country, the profession of land surveyor always respects honour because it is devoted to the invaluable treasures of Ukraine - land, which has always attached special significance. 
According to the research conducted in Ukraine, soon, the 10 most demanded professions include: programmers ( $\mathrm{C}++$, Java), food industry technologists, construction engineers, architects, designers of offices and interiors, personnel managers, recruiters, energy engineers, journalists, technologists of light industry products, financiers (specialization "banking") [1]. In addition, prospective include: hotel business managers, accountants, auditors, lawyers, marketers.

According to the Ministry of Education and Science of Ukraine, according to the results of the 2017 admission, the most popular specialties among the entrants for the Bachelor in Ukraine were Philology, Law, and Management. 85 thousand, 74 thousand and 59 thousand applications have been filed for the stated above specialties respectively. In addition, among the leaders are "Medicine", "Computer Science", "Tourism", "Secondary Education", "Psychology", "Economics". These specialties were desirable to enter by 40 to 46 thousand of entrants. The last step in the TOP-10 was "Software Engineering" with the result of 33 thousand applications (Fig. 1) [9].

Despite the stated above facts, it has been revealed that such specialties as "Law", "Management", "Tourism" and "Economics" remain among the most popular among entrants even though they are not in demand in the labour market. At the same time, the high levels in the ranking are occupied by important for the economy specialties, such as "Computer Science" and "Software Engineering". The least popular specialties are (fig. 2) "Theology" (185 applications excluding spiritual higher educational institutions) and "Hydropower" (193 applications for entry).

However, specialties for the preparation of a specialist in land management are absent among the most and least popular. Therefore, with a caution we have to perceive the situation.

The list of required occupations in the labour market is changing. Focus magazine has ranked the professions that will be promising in 5-10 years [10]. Before allocating the most promising specialties, the publication together with experts identified the areas of the economy that will actively develop in the near future. So, at first there was a list of 40 spheres of the economy, which, according to Focus, will successfully develop in the next 5-10 years. Experts evaluated the prospects for the development of these industries on a 10-point scale, giving each sector a mark from 1 to 10 points. At the same time, each expert could add to the list the industry that was not among the 40 listed, but whose potential he considers rather large.

According to the obtained data, the rating of 15 most promising industries has been designed, and include: information technologies, telecommunications and communications, agriculture, pharmaceutical production and pharmacy business, banking, frying and processing industry, transport services, financial services, legal services, household services, metallurgy, alcohol production, energy, livestock, utilities.

So, the 20 most promising professions of the next decade will be the following: the seller, the IT specialist, the automation engineer, the marketer, the municipal services engineer, the aeroengineer, the technologist in the production and processing of food products, the 
technologist of consumer services, logistics, the lawyer (economic and land law), power engineer veterinarian, pharmacologist, financier, communication engineer, practical psychologist, geneticist, biochemist, robotic technician, nanoengineer.

In addition, agrarian countries are actively developing organic and farm farming. This will require the involvement of a large number of employees who are able to work on the ground and thus, forms a serious niche. In general, the labour market trends in the coming years can be reduced to nine main directions [5]: engineers, IT specialists, nanotechnology specialists, marketers, service providers, logistics, environmentalists, chemists, and physicians.

The Resolution of the Cabinet of Ministers of Ukraine dated December 30, 2015, No. 1187, approved new Licensing conditions for the conduct of educational activities [7] concerning the further conduct of educational and scientific work in educational institutions. By the order of the Ministry of Education and Science dated November 6, 2015, No. 1151 "On the peculiarities of the introduction of the list of branches of knowledge and specialties [6], which are the training of applicants for higher education, approved by the Cabinet of Ministers of Ukraine from April 29, 2015, No. 266" [8] approved Table of correspondence List of directions for training of specialists in higher educational establishments for the educational-qualifying level of bachelor (List 1), List of specialties, which was carried out training of specialists in higher education institutions for educational and qualification levels of a specialist and a master's degree (List 2).

In the stated above Resolution, it is defined that instead of the specialties "Land Management and Cadastre" and "Land and Real Estate Valuation" - the specialty "Geodesy and Land Management" is established. The latter belongs to the field of knowledge "Architecture and Construction", which belongs to the technical sciences.

At the same time, the Law of Ukraine "On Land Management" stipulates that land management is a set of socio-economic and environmental measures aimed at regulating land relations and rational organization of the territory of administrative-territorial units, economic entities carried out under the influence of social and productive relations and development of productive forces [2]. The same law (Article 1) stipulates that activities in the field of land management are the scientific, technical, production and management activities of state authorities, local governments, legal entities and individuals, which is carried out under land management. Land-use documentation (land management documentation) is the text and graphic materials approved in accordance with the established procedure, which regulate the use and protection of lands of state, communal and private property, as well as survey and land survey materials, author's supervision of project implementation, etc. Measures on land management - provided by documentation on land management on the rational use and protection of land, the formation and organization of the territory of the object of land management, taking into account their purpose, restrictions on the use and restrictions (encumbrances) on the rights of other persons (land servitudes), preservation and increase of fertility soils.

This is evidence that the profession of land surveyor is more likely to belong to the field of knowledge of "Social and behavioural sciences" than to "Architecture and construction".

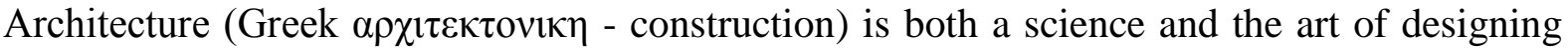
buildings, as well as a system of buildings and structures that form a spatial environment for the lives and activities of people in accordance with the laws of beauty. Land management, as 
stated in the Law of Ukraine "On Land Management" - a set of socio-economic and environmental measures aimed at regulating land relations and rational organization of the territory of administrative-territorial entities and economic entities on the ground.

As the research of A.M. Tretiak and V.M. Tretiak shows, the concept and essence of land management has both a technical direction and socio-economic, legal and environmental.

Land managers have worked and work in the structural subdivisions of the State Committee for Land Resources of Ukraine, the State Land Agency of Ukraine and the State Audit Office of Ukraine, state authorities and local self-government bodies, and ministries (where there are departments of land resources); in public and private design and valuation companies, real estate firms, agroholdings, agricultural enterprises; territorial communities, scientific institutions, institutions of legal direction. civic organizations.

The land manager learns not only his professional knowledge, but also legal and natural sciences. For a profession it is necessary to have mathematical abilities, engineering approach, spatial imagination, ability to understand the legislation. The profession is extremely interesting and creative, which requires the ability to make informed decisions, communicate with people, requires care, clarity and responsibility. To become a successful specialist in this field, you need to be persistent, self-confident, active, have a well-developed intuition and logical thinking.

According to the classification of professions, the professional activity of the land manager relates to professions such as "human-nature". To date, the land manager must have a higher education in the field of "Architecture and Construction" from the specialty "Geodesy and Land Management", according to the educational qualification level: a junior specialist, a bachelor's or a master's degree.

Currently, land managers use modern equipment in their work: electronic instruments; new technologies of geographic information systems. Significant problems arise when making managerial decisions due to the imperfection of the regulatory framework - when three different land managers can have three different views on the same issue. At the same time, for professionals it is extremely important to come to a joint decision. But how can the problems of legislation be explained to an ordinary peasant? It's a shame when you can not help a person in solving his question, and even more - when you do not know how to explain the impossibility of solving a particular problem. The disadvantage of the profession is also that there is little free time for personal life, family and wage mismatch in modern times. The advantages include: work is interesting, lots of communication, new knowledge in land law, and more.

At the same time, we consider it necessary to stay on the proposals of A. Martyn outlined in the scientific paper "Directions of adaptation of the content of land management education to the needs of the national and world economy" [3], where he publishes "bad news" for land management education - whether we are ready for them? He states: "Most of our graduates will not develop landuse documentation at all; the number of jobs in the industry is quite limited; the overwhelming part of the "modern" Ukrainian land management is a terrible mix of fairly archaic rules, a crazy bureaucracy and meaningless rituals, in order to master the development of primitive land management documentation, it takes 2-3 weeks of practical 
training, but not 5 years at the university, and a significant part of cadastral registrar are lawyers.

Some of these reservations agreeable. Therefore, his thoughts emphasize once again the need for serious changes in the training of land management specialists.

Thus, all of the above stipulates the need for changes in the classification of occupations DK 003: 2010 and the definition of new specialties and specialization training of land management specialists.

In our opinion, it is expedient to extend the training of specialists in land surveying in the following areas: 1) specialty 193 "Geodesy and land management" of the specializations "Land Management and Land Use Administration" and "Cadastral Registrar"; 2) specialty 101 "Ecology" specialization "Land management and ecologization of land use"; 3) specialty 051 "Economics" specialization "Economics of land management and land use".

At the same time, we consider it expedient to add the following qualifications to the classifier of professions DK 003: 2010: in section 8 "Main specialists - heads of scientific research units and subdivisions on scientific and technical preparation of production and other managers" - Chief land surveyor; in section 14 "Managers of enterprises, institutions, organizations and their subdivisions" - Manager of land management, Manager in the field of operations with land, Manager in the field of research in the land market; in section 25 "Agronomists, hydraulic engineering, forest managers and professionals of related professions" - Land manager; in section 33 "Assistant veterinarians, junior specialists in agronomy, forestry, water management and nature conservation" - Land Resources Inspector; in section 34 "Other technical specialists in the field of management" - State Inspector for the use and protection of land; in section 249 "Professionals not included in other classification groups". Land manager-ecologist, Land manager-designer.

Conclusions.Summing up, we note that the assignment of the specialty "Geodesy and land management" to the field of knowledge "Architecture and Construction" (engineering science) does not comply with the provisions of the Law "On Land Management", the study of world experience of the essence of the concepts of land management, which determined that they are inherent in technical, as well as socio-economic, legal and environmental trends. In this connection it is proved that the profession of land manager belongs to the field of knowledge of "Social and behavioral sciences".

In view of this, the need for re-engineering the directions of land management training is urgent. Therefore, we must work ahead and make changes to the classification of professions DK 003: 2010 regarding the definition of new specialties and specialization training of specialists in land management. We consider it expedient to expand the training of specialists within: 1) specialty 193 "Geodesy and land management" of the specialties "Land Management and Land Use Administration" and "Cadastral Registrar"; 2) specialty 101 "Ecology" specialization "Land management and ecologization of land use"; 3 ) specialty 051 "Economics" specialization "Economics of land management and land use" (qualification "Land Management Manager"). It is proposed to make changes to the list of qualifications.

\section{References}


1. Ipress.ua, "10 most demanded professions in Ukraine in the near future", Available at: http://ipress.ua/lijlive/10_naybilsh_zatrebuvanyh_profesiy_v_ukraini_v_nayblyzhchomu_may butnomu_7916.html (Last viewed 20.03.2018);

2. The Law of Ukraine "On Land Management" 2003. Kyiv, VidomostiVerkhovhoi Rady Ukrainy;

3. Martyn A. (2018), "Higher education in geodesy and land management: time to change the priorities of learning?", Zemlevporiadnyivisnyk, no. 2, pp. 30-36;

4. Martyn A. (2009), "Content of higher education in the field of land management: the current state, problems and solutions", Zemlevporiadnyivisnyk, no. 5, pp. 32-36;

5. ILady, "The most demanded profession in 2017”, Available at: https://www.ilady.in.ua/2015/09/professii.html (Last viewed 20.03.2018);

6. Order of the Ministry of Education and Science No. 1151 "On peculiarities of introduction of the list of branches of knowledge and specialties", Available at: http://zakon5.rada.gov.ua/laws/show/z1460-15 (Last viewed 21.03.2018);

7. Resolution of the Cabinet of Ministers of Ukraine No. 1187 "On Approval of Licensing Conditions for Educational Activities of Educational Institutions", Available at: http://zakon5.rada.gov.ua/laws/show/1187-2015-ח (Last viewed 21.03.2018);

8. Resolution of the Cabinet of Ministers of Ukraine No. 266 "On approval of the list of branches of knowledge and specialties under which higher education applicants are trained", Available at: http://www.kmu.gov.ua/control/ru/cardnpd? docid=248149695 (Last viewed 21.03.2018);

9. 5.ua, "TOP-10 of the most popular professions among entrants in Ukraine - infographics", Available at: https://www.5.ua/suspilstvo/top10-naipopuliarnishykh-profesii-seredvstupnykiv-v-ukraini-infohrafika-155068.html (Last viewed 22.03.2018);

10. Ukraiinskapravda, "TOP-20 of the most promising professions", Available at: http://life.pravda.com.ua/society/2009/08/28/25602/ (Last viewed 22.03.2018);

11. Tretiak A., Tretiak V., Pendzei L. (2016), "Status and problems of training, advanced training and retraining of personnel in the field of land management", Zemleustrii, kadastrimonitorynhzemel, no. 1-2, pp. 128-135. 